\title{
Effect of Forensic Accounting on the Detection of Fraud Risk Indicators in Public Enterprises in Ondo State, Nigeria
}

\author{
Oluwatuyi, Akinwumi Samuel \\ Department of Accounting, Kogi State University, Anyingba, Nigeria
}

\begin{abstract}
This study is on effect of Forensic Accounting on the Detection of Fraud Risk Indicators in Public Enterprises in Ondo State, Nigeria; the main objective of this research is to examine the effects of forensic accounting on detecting fraud risk indicators in the public enterprises in Ondo State. The study population comprised of the entire staff of the public enterprises in Ondo State with a sampled population of 238 purposively targeted two groups of respondents. The study sourced primary data through the use of questionnaire, while secondary sources were text books, published materials like journals and internet facility. The study made use of statistical package for social sciences (SPSS 21) software to present the data. The z-test research techniques were used to analyze and interpret collected data with reference to stated hypotheses. The study results revealed that Forensic Accounting does have significant effect with regards to detection of fraud risk indicators in Public Enterprises. That is, effective use of the forensic accounting could help in the detection of fraud risk indicators that often leads to continuous perpetration of fraud in the Public Enterprises in Ondo State. Therefore, the study recommend that: Government should endeavour to increase the use of forensic accounting in other government parastatals and agencies; there is need for value re-orientation training and seminar to renew the mindset of the employees towards integrity and upright living style; and establishment of risk control department and workable risk management framework will reduce fraudulent activities in the public enterprises.
\end{abstract}

Keywords: Forensic Account; Fraud Theory; Fraud Risk Indicators; Public Enterprises.

DOI: $10.7176 /$ RJFA/10-14-06

Publication date:July $31^{\text {st }} 2019$

\section{Introduction}

Statements of Auditing Standards (SAS) No 1 states that, in exercising professional skepticism, an auditor "neither assumes that management is dishonest nor assumes unquestioned honesty." In practice, maintaining this attitude of professional skepticism can be difficult because, despite some recent high profile examples of fraudulent financial statements, material frauds are infrequent compared to the number of audits of financial statements conducted annually. Statements of Auditing Standards (SAS 99) provides guidance to auditors in assessing the risk of fraud - they must maintain a level of professional skepticism when considering a broad set of information, including fraud risk factors to identify and respond to fraud risk.

In order to overcome the challenges being faced by traditional auditing system in the business and nonbusiness organization thus called for employing forensic examination of accounting records. Forensic accounting otherwise called investigative accounting or fraud audit is a merger of forensic science and accounting.

Emerging researches are laying credence to the fact that forensic accounting skills and techniques could help to investigate fraud occurrence especially when acquired by external auditors to be able to tackle modern frauds like white collar crimes such as security fraud, embezzlement, bankruptcy, contract disputes, and possible criminal financial transactions; including money laundering by organized criminals (Gbegi, \& Adebisi, 2014).

Therefore, Accountant should be able to identify the pattern of abuse by having effective investigation skills and analytical thoughts and excellent communication skills. Nigeria's public enterprises are generally corporate entities other than ministerial departments, they derive their existence from special statutory instruments; and engage in business type of activities to provide goods and services for the overall social and economic upliftments of the citizen. These include corporation, authorities, boards, companies and enterprises so owned and operated (Jerome, 1999). The non-performance of the public enterprise has prompted series of discussions and policy recommendations on how best to move them out of their present quagmire.

In essence, the use of forensic accounting for the detection of fraud related problem in the public enterprises becomes a necessity going by spate of inefficiency and gross financial misconduct made possible by corrupt practices. Hence, this study seeks to find out how forensic accounting can be used to detection of fraud risk indicators in the Nigerian public enterprises using Ondo State as a case study.

\section{Statement of the Problem}

Fraud has being a global diseases and also become order of the day to the extent that no country either at federal, state or local government level including private and or public sector can proudly lay claim to zero fraud (Okoye \& Gbegi, 2013).

Nigeria's public enterprises are generally corporate entities other than ministerial departments, they derive 
their existence from special statutory instruments; and engage in business type of activities to provide goods and services for the overall social and economic upliftment of the citizen. These include corporation, authorities, boards, companies and enterprises so owned and operated (Jerome, 1999). The non-performance of the public enterprise has prompted series of discussions and policy recommendations on how best to move them out of their present quagmire. It was for these reasons that in 1999, the Democratic regime under the leadership of President Olusegun Obasanjo, initiated various reforms across the various sectors of the Nigerian economy. Where they recognized that national public enterprises have failed to meet public expectation, they were conceived to be consuming a large proportion of national resources without discharging the responsibilities thrust upon them. It was also established facts, such as the following: That they create economic inefficiencies, they incur huge financial losses, they absorb disproportionate share of credit especially in the form of foreign loans (Oluade, 2007).

As such, it appears the incorporation of forensic accounting techniques in Nigerian public enterprises will assist in preparing the accounting profession to deal effectively with the problem through the process of unearthing ingenious fraud been perpetrated in the Nigerian public enterprises. The challenges associated with fraud related problem cannot be played down in most public enterprises in Nigeria. This has over the years contributed a great hindrance to the soundness and growth of public enterprise businesses. The case with Ondo State being a state in Nigeria is not different from the challenges highlighted above.

As a consequence, attempt is being made by researchers to know whether fraud related issues are brought under control that is to the bearest minimum level through the engagement of forensic accountants. One of the breakthroughs in this regard is the use of forensic accounting techniques as it relates to fraud risk indicators which have changed the modus operandi of financial and economic dealings in the public enterprises in Ondo State, Nigeria. It is expected that Forensic Accounting should come with the following successes in regard to use: Check on Security fraud; business valuation; level of bankruptcy or insolvency of business enterprise; and determination of economic damages.

Hence, this study seeks to examine the use of forensic accounting in the face of fraud risk indicators as a tool for mitigating the effect of fraud in public enterprises in Ondo State, Nigeria.

\section{Objectives of the Study}

The main objective of this work is to examine the effects of forensic accounting on detecting fraud risk indicators in the public enterprises in Ondo State, Nigeria. The study also has the following specific objectives to:

i. examine how forensic accounting can be used in detecting situational pressures related to fraud risk indicators in the public enterprises in Ondo State, Nigeria.

ii. examine how forensic accounting can be used in detecting personal characteristics related to fraud risk indicators in the public enterprises in Ondo State, Nigeria.

iii. examine how forensic accounting can be used in detecting opportunities related to fraud risk indicators in the public enterprises in Ondo State, Nigeria.

iv. examine how forensic accounting can be used in detecting capabilities related to fraud risk indicators in the public enterprises in Ondo State, Nigeria.

\section{Research Questions}

Based on the research problem and to achieve the stated objectives of the study, the following research questions are derived.

i. Does forensic accounting help in detecting situational pressures related to fraud risk indicators in the public enterprises?

ii. How forensic accounting help in detecting personal characteristics related to fraud risk indicators in the public enterprises?

iii. Does forensic accounting help in detecting opportunities related to fraud risk indicators in the public enterprises?

iv. How forensic accounting help in detecting capabilities related to fraud risk indicators in the public enterprises?

\section{Research Hypotheses}

For the purpose of this study, the hypothesis testing shall be formulated in their null form, stated thus:

i. $\mathbf{H}_{\mathbf{0}}$ : Forensic accounting has no significant effect in detecting situational pressures related to fraud risk indicators in the public enterprises.

ii. $\mathbf{H}_{\mathbf{0}}$ : Forensic accounting has no significant effect in detecting personal characteristics related to fraud risk indicators in the public enterprises.

iii. $\quad \mathbf{H}_{\mathbf{0}}$ : Forensic accounting has no significant effect in detecting opportunities related to fraud risk indicators in the public enterprises.

iv. $\quad \mathbf{H}_{\mathbf{0}}$ : Forensic accounting has no significant effect in detecting capabilities related to fraud risk indicators in 
the public enterprises.

\section{Significance of the Study}

Accounting practices has improved tremendously, but recent electronic frauds have become complex and sophisticated to a magnitude that they could go unrecognized (Haynes, 2009).

This research provides a framework for identifying the influence of fraud theory on forensic accounting and fraud risk indicators.

This work is significant to the public and also private sectors because it enlightens them the influence that fraud theory has on forensic accounting and fraud risk indicators most especially the business enterprises.

Also, the society at large will have a better understanding on forensic accounting and fraud risk indicators.

Students would discover that the basic fraud risk indicators is significantly differ, based on the complexity of different business enterprises or organization in public and private enterprises, this study will be very useful.

\section{Scope of the Study}

This study aimed at examining the effect of forensic accounting on the detection of fraud risk indicators in public enterprises in Ondo State, Nigeria. The scope of the study is centered on public enterprises, since the public enterprises are commercialized businesses of government and not immune from fraudulent activities of fraudsters. In addition, The study also focus on fraud risk indicators like situational pressures, personal characteristics, opportunities, and capabilities and their effects on public enterprises in Ondo State, Nigeria.

The work is focused on two (2) groups of respondents working in public enterprises as follows: (i) Accountants; and (ii) Auditors.

\section{Literature Review}

\section{Conceptual Framework}

Concept of Fraud: The Institute of Turkish History explains the word fraud as "a deceptive trick, scam, game, artifice, cabal which is committed to cheat, mislead someone" and "contributing something useless to something in order to gain advantage".

According to Anyanwu (1993), fraud is an act or course of deception, deliberately practiced to gain unlawful or unfair advantage; such deception directed to the detriment of another. Many frauds would not have occurred without the right person with right capabilities implementing the details of the fraud (Wolf \& Hermanson 2004). Gbegi \& Adebisi (2013) as cited Wells (2011) sees fraud as different from error, which refers to "unintentional misstatement or omissions of amount or disclosures from an entity's accounting records or financial statements."

Dada, Owolabi \& Okwu (2013) cited EFCC (2004) that Fraud has been defined as “. . . the non-violent criminal and illicit activity committed with objective of earning wealth illegally either individually or in a group or organized manner thereby violating existing legislation governing the economic activities of government and its administration..."

Drawing from all of conceptual definitions above, fraud according to this study is a deliberate action made by an individual or group of persons with the intention to take an unlawful advantage at the expense of the other party.

Forensic Accounting as a Concept: According to Association of Certified Fraud Examiners (2012) says forensic accounting "is the use of skills in potential or real civil or criminal disputes, including generally accepted accounting and auditing principles; establishing losses of profit, income, property or damage, estimations of internal controls, frauds and other that involves inclusion of accounting expertise into the legal system". Forensic accountants provide services in accounting, auditing investigation, damages claims, analysis valuation and general consultation and also have critical roles in divorce, insurance claims, personal damage claims, fraud claims, construction, auditing of publication right and in detecting terrorism by using financial precedence (Hassan \& Morteza, 2012).

In other words, forensic accounting or otherwise called investigative accounting involves the application of accounting concepts and auditing techniques in solving legal problems.

The opinion of Coenen (2005) said that forensic accounting involves the application of accounting concepts and techniques.

Dhar \& Sarkar (2010) define forensic accounting as the application of accounting concepts and techniques to legal problems. Zysman, (2001) says forensic accounting provides an accounting analysis that is suitable to court, which will form the basis of discussion, debate and ultimately dispute resolution. Forensic accounting investigations include litigation services related to a variety of situations including business purchases, valuation of divorce assets, property damage, lost profits due to embezzlement and other illegal acts, tax evasion, and money laundering schemes (Gray 2008).

A forensic accountant will be considered independent if they are intellectually honest, ready to make impartial decisions and have no interests or obligations in relation to the client, management or the owner. 
Hence, according to many, the key components of forensic accounting are accounting skills, auditing techniques and investigative procedures.

Fraud Risk Indicators (Red Flags) as a Concept: Kennedy \& Anyaduba (2013) says that forensic accounting is a tripartite practice of utilizing accounting, auditing and investigative skills to assist in legal matters. Fraud risk indicators are set of circumstances that are unusual or deviated from the usual activity (Abdullahi \& Mansor, 2015). According to Abdullahi \& Mansor (2015) opine that there are set of circumstances that are unusual or deviated from the usual activity. That is a signal (indicator) that shows something is out of the ordinary and may need to be investigated further. Fraud Risk Indicators does not indicate that fraud had occurred or not but merely provide possible warning signs of fraud. Then base on Abdullahi \& Mansor (2015), their work revealed that there some identified fraud risk indicators which also known as red flags.

Public Enterprises as a Concept: There appears to be no universally agreed definition among scholars regarding the conceptual meaning of public enterprises. According to Laleye (1985) the bewildering number and types of the organizations called 'public enterprises' their different contents and the rationale for which they are set up accounts for lack of authoritative and generally acceptable definition of public enterprises. Sosna (1983) opined that there are many reasons why in developed capitalist countries, there is no single standard definition of public enterprises. Public enterprises were established at different periods, and each epoch naturally brought forth the types of public enterprises most clearly matching its own conditions. It is therefore believed that the variation in definition are informed by the ideological, values, interests, dispositions and circumstances that brought public enterprises into existence. Whatever the controversy and the lack of uniformity might conjure up, we would however review the viewpoint of some scholars of public enterprises. For instance, Efange (1987) define public enterprises or parastatals as institutions or organizations which are owned by the state or in which the state holds a majority interest, whose activities are of a business in nature and which provide services or produce goods and have their own distinct management.

Obadan (2000), Obadan \& Ayodele (1998) defined public enterprises as organizations whose primary functions is the production and sale of goods and/or services and in which government or other government controlled agencies have no ownership stake that is sufficient to ensure their control over the enterprises regardless of how actively that control is exercised. In another dimension, Nellis (1986) refuses to give a precise definition of public enterprise, but only adduced reasons for its creation. He observed that there are many reasons that explain why African states have created and sustained public enterprises. "Institutions and pre-dispositions inherited from centralized interventionist colonial regimes; a tendency to associate liberal capitalism with colonialism and imperialism; the post war ascendancy of leftist/statist political ideologies; the apparent absence or embryonic nature of the indigenous private sector; the conversion of failing private enterprises into public enterprises to forestall increases in employment; the attractiveness of public enterprises to politicians who use them as patronage mechanisms to distribute jobs to both the mighty and the minor - these are but some of the more important historical economic, social and political factors which have led almost every African state to create large public enterprise sector".

A brief on Forensic Accounting and Fraud Detection: Statement on Auditing Standard (SAS ) No 99, which has been developed and issued by the Auditing Standards Board of the American Institute of Certified Public Accountants (AICPA) in October 2002 were originally established in response to the wide occurrence of global; local; and corporate scandals in an organization. For examples Enron, Parmalat, Worldcom, BCCI, Transmile, Megan Media, Cadbury and collapsed of some financial institutions in Nigeria).

KPMG's Fraud Survey (2003) reveals that more companies are recently experiencing incidents of fraud than in prior years; taking measures to combat fraud; and launching new antifraud initiatives and programs in response to the Sarbanes - Oxley Act of 2002 (KPMG 2003). PricewaterhouseCoopers' (PWC) 2003 Global Crime Survey also indicates that 37 percent of respondents in 50 countries reported significant economic crimes with the average loss per company of \$2,199, 930 (PWC 2003).

In view of this development that SAS No. 99 was issued and enforced in order to prevent economy from total collapse. This SAS No 99 describes a process wherein the auditor: (1) gathers information needed to identify risks of material misstatement, (2) assesses these risks after taking into account an evaluation of the entity's programs and controls, and (3) responds to the results. Under SAS No. 99, the auditor must gather and consider much more information to assess fraud risks than in the past (Ramos 2003). This process involves gathering information and assessing firms' fraud risk indicators.

In an effort to prevent and detect any fraud or precisely financial statement fraud, the International Federation of Accountants (IFAC) which Institute of Chartered Accountants of Nigeria (ICAN) and Association of National Accountant of Nigeria (ANAN) were members, has specifically introduced an International Standard for Auditing - AI240. In essence, AI240 represents the auditor's responsibility to consider fraud in an audit of financial statement or any other assurance engagement. The responsibility of investigating, detecting and preventing frauds in financial statements lies in the hands of the management of an enterprise, but also in the hands of other control institutions and mechanisms. 


\section{Theoretical Framework}

White Collar Crime Theory: White-collar crime is a crime committed by a person of respectability and high social status in the course of his occupation (Sutherland, 1949). Corporate crime and occupational crime are viewed as "the two principal or "pure' forms of white-collar crime" (Friedrichs, 2002). The researchers defined whitecollar crime as illegal or unethical acts that violate fiduciary responsibility or public trust for personal or organizational gain" (Kane \& Wall, 2006). According to Abdullahi \& Mansor (2015) cited Wolfe \& Hermanson (2004) quoting Sutherland (1977) "Theory of White Collar Criminals" state that, "As fraudsters found themselves successful at this crime, they began to gain some secondary delight in the knowledge that they are fooling world, that they are showing their superiority to others". Sutherland theory on fraud was coined as theory of differential association that: (1) Crime is learned; (2) Not genetic; and (3) Learned from intimate personal groups. Thereby, he (Sutherland) submitted in his book that most crime committed were from people of good background. His attention was called to prove that criminal activities were not only of the business of lower class people but including those of the upper class. Sutherland was criticized based on the following ambiguity: (i) conceptual, (ii) empirical, (iii) methodological, (iv) legal, and (v) policy. Despite the criticism of Sutherland on the proposition of White Collar Crime Theory, his work still has impact on how fraud is being perpetrated.

Fraud Triangle Theory (Donald Cressey, 1950): This theory was originally developed in order to investigate the causes of fraud and it provides an explanation as to why people commit fraud. In 1953 Cressey affirm that, there are three factors that are present in every situation of fraud; they are: perceived pressure, opportunity, and rationalization. Pressure is a situation where the prospective fraudsters are faced with financial, work or personal pressures. They then look for short-term options to solve their problems and in most cases; fraud is one possible alternative solution. Then, there is opportunity to commit fraud. Such opportunity could be in the forms of trust given by the company to the prospective fraudsters who take care of important functions within the organizations or when the company's own internal control system is weak. Opportunity opens the doorway to fraud; and Rationalization (attitude): The attitude set of ethical beliefs that enable certain party (s) to commit fraud, or a different person in an environment that makes them justifies their fraudulent actions. Albrecht argued that there are nine motivators of fraud. They are: living beyond means; Overwhelming desire for personal gain; High personal debt; Close association with customers; Pay not commensurate with the job; wheeler-dealer; Strong challenge to beat the system; Excessive gambling; and Family or pear pressure.

Broken Trust Theory: Albrecht, Albrecht \& Albrecht (2004) introduced this theory to explain corporate executive Fraud. They (Albrecht et al 2004) combined the Fraud Triangle concept, the Agency theory, and the Stewardship theory to develop a "Broken Trust" theory of corporate executive Fraud. The Broken Trust theory explains corporate executive Fraud in a matrix that links the three variables to corporate executive whose behavior is either consistent with the Stewardship theory or Agency theory; whose corporate structure is either consistent with the Stewardship-based structure or Agency-based structure, and whose compensation is either consistent with the Stewardship-based rewards and incentives or Agency-based rewards and incentives.

The Cressey and Albrecht et al matrix conclude that, to a meaningful degree, executives self-identify with behavior either more consistent with the Agency theory or Stewardship theory of management, and that those whose behavior is, in fact, more consistent with Stewardship theory are more trustworthy and generally less likely to commit Fraud. Albrecht et al.'s Broken Trust theory principle is that both the Agency theory and Stewardship theory share a common element, "transference of some measure of trust from shareholders to executive level managers," and when executives commit fraud they intentionally break the trust and betray shareholders. The theory has two key limitations. First, a vast majority of management research in Agency and Stewardship theories addresses executive behavior in stable or growing companies, but not in companies involved in Fraud (Daily, 2003). Therefore, the Broken Trust theory, based on the Agency and Stewardship theories, assumes it can explain executives' fraudulent behavior in both Fraud and non-Fraud companies. Such assumption is weak given that there is very little evidence in the Agency and Stewardship theories that addresses executive behavior in companies involved in Fraud. Second, it is assumed that the Broken Trust theory relate well to the first two variables (Pressure and Opportunity) of the Fraud Triangle concept, but not the third variable (Rationalization) because Albrecht et al. (2004) provide very little explanation on why or how the corporate executives would rationalize their fraudulent behavior under the Broken Trust theory.

Fraud Diamond Theory: This is an extension of Fraud Triangle Theory (FTT), which was made by Wolfe \& Hermanson (2004). They introduced another fraud dimension (that is Capability) to complement the earlier work by Cressey and renamed the original fraud triangle to Fraud Diamond Theory. They believed that the FTT could be enhanced to improve both fraud prevention and detection by considering an additional element "capability". In addition to addressing, perceived pressure, perceived opportunity, and rationalization, Wolfe and Hermanson considered an individual's capability, which comprises the personal traits and abilities to commit fraud. Capability depicts the personal characteristics of the fraudster. The recognition of the element of capability has involved the six factors expected to be achieved by the fraudsters as described by Wolfe \& Hermanson (2004) as follows: positioning, intelligence, ego, coercion, deceit, and stress management. 
The New Fraud Diamond Model (Gbegi \& Adebisi, 2013): In their proposition, they argue that all other fraud models should be regarded as an extension to Wolf and Hermanson's Fraud Diamond and be integrated in one model that includes motivation, opportunity, personal integrity, capabilities and corporate governance. They called it "New Fraud Diamond Model". Gbegi \& Adebisi posited that the "corporate governance" that was added to the existing diamond theory will make forensic accounting practitioners to have in-depth knowledge of fraud and why it occurs. The essence of their model to help them in identify those forensic accounting practitioners must understand how fraud is being perpetrated in order to give room for effective investigation and assessing fraud risk. They submitted that forensic accountants need to understand the opportunity for fraud through the new fraud diamond model to ying and investigating which fraud schemes an individual can commit and also in effectively assessing fraud risk.

Theoretically, frauds are easier to commit if the fraudster is coercive, confident and has the power or authority to make direct decisions. Opportunity opens the doorway to fraud; pressure and rationalization draw a person toward it. Prospect fraudsters must have the capability to recognize the open doorway as an opportunity to take advantage of it. From a business perspective, the possibility for fraud and extortion typically impinges on the regulatory gates, transactions with public officials; obtaining import or export permits and visas, paying for public utilities and taxes, loan applications, award of public contracts, influencing laws and regulations, and getting favourable judicial decisions (Kaufmann, 2003)

\section{Justification and Application of theory}

This study is anchored on "fraud diamond theory" by Wolf \& Hermanson (2004) and by extension "The New Fraud Diamond Theory" pro-pounded by Gbegi \& Adebisi (2013) because public enterprises in Nigeria are not immune to fraud as put forward by this theory. The theory established that fraudsters exhibit a level of confidence that makes them believe that they cannot be caught. But the case in Nigeria is such that when they are caught nothing or no measure of punishment may meted out to them. This has in away encouraged the perpetration of fraud in the Nigeria system.

Therefore, the justification for this theory choice is based on the fact that the theory gives a pragmatic approach to its explanation as to why people get involve in fraudulent acts. The reasons adduced are quite germane to the practice of fraud in most public enterprises in Nigeria. Besides, the SAS No. 99 was developed and issued by the Auditing Standards Board (ASB) of the American Institute of Certified Public Accountants (AICPA) which identifies various related fraud risk indicators. Wolf \& Hermanson summarized the four conditions that are present when fraud occurs as follows:

Pressure: management or other employees may have an incentive or be under pressure, which provides a motivation to commit fraud.

Opportunity: circumstances exist (i.e., the absence of controls, ineffective controls, or the ability of management to override controls) that provide an opportunity for fraud to be perpetrated.

Rationalization: those involved in a fraud rationalize a fraudulent act as being consistent with their personal code of ethics. Some individuals possess an attitude, a character or a set of ethical values that allow them to knowingly and intentionally commit a dishonest act (Ramos 2003).

Capability: fraudsters must possess six or any combination of capability traits to commit fraud. Austin, (2014) quoted Hay, (2013) that capabilities have six supporting traits: positioning, intelligence, ego, coercion, deceit, and stress management..

These four dimensions of fraud involvement find practical relevance in the Nigerian public enterprises with reference to the study area, Ondo State. As such, it is applicable to the study focus given the reasons why people involve in fraudulent act in our system here.

\section{Empirical Studies}

There are researchers that have done a lot on this issue of using forensic accounting to detecting and preventing of fraudulent activities, such like Tugas (2012); Olukowade \& Balogun (2015); Okoye \& Gbegi (2013); Okafor (2004), Gbegi \& Adebisi (2015). In addition, Wolf \& Hermanson (2004) also revealed in their study the influence of fraud diamond theory (FDT) in identifying and assessing the risk of fraud occurrence. Centre for Forensic Studies (2010) report that forensic accounting could also be used to reverse the leakages that cause corporate failures.

Gbegi \& Adebisi (2014) carried out a study on forensic accounting skills and techniques in fraud investigation in the Nigerian public sector. They focus on examining the skills and techniques used in investigating fraud in Nigeria public sector. The method they employed includes primary and secondary data using questionnaire for primary data while they use secondary data to obtained data from EFCC, ICPC and CCB and were used for the testing of hypotheses by using Analysis of variance (ANOVA) and time series analysis with the aid of SPSS version 17.0. Their findings reveal that forensic accounting skills and techniques have significant effect on uncovering fraud and reducing fraud in the Nigerian public sector. In their research work they recommends that: 
(1) anti-corruption agencies in Nigeria should establish forensic units and forensic laboratories to allow room for more effective and efficient investigation of suspected and confirmed fraud cases; and (2) the public sector (government) should develop interest in forensic accounting by making sure that forensic accounting is institutionalized in all ministries, extra-ministerial departments and parastatals to build up effective internal control system that will enhance more effective performance in Nigerian public sector.

Enofe, Olorunnuho \& Eboigbe (2015) carried out a study on accountants' perception of forensic accounting and fraud investigation. Quota sampling method was adopted for their study. They use sample size of two hundred (200) professional accountants, practicing in firms, mid level employee and senior accountant with academic accountant drawn from the population of the professional Accountants in Edo State. The data generated were analyzed through mean scores while the stated hypotheses were statistically tested with Chi-test. Their findings revealed a general opinion for the need of the services of forensic accountants in Nigeria economy and their services are more required for fraud and corruption related issues. They recommend that, the Institute of Chartered Accountant of Nigeria (ICAN) should encourage formalization and specialization in the field of forensic accounting; the government should develop interest in forensic accounting and accountants for monitoring and investigation of suspected and confirmed corruption cases; and practicing accountant should work towards specialization and possibly establish firm for forensic accounting practice (Enofe, Olorunnuho \& Eboigbe, 2015).

Enofe, Okpako \& Atube (2013) carried out a study on the impact of forensic accounting on fraud detection. They examine the effect of forensic accounting on fraud detection in Nigerian firms. The aim of their study is to determine the relationship between fraud detection and forensic accounting. The methodology adopted to analyze their data was descriptive statistics using ordinary least square (OLS) regression and Chi-square with the help of a well-structured questionnaire administered to fifteen firms (15) in Benin City Edo State. The findings of their study reveal that the application of forensic accounting has strong relationship with fraud detection for public confidence and eradication of crime and corruption in Nigerian economy. They recommends that, Government and regulatory authorities should provide standards and guidelines to regulate forensic activities; for the development, employment and the standard of living of the people to improve there must be total eradication of economic and financial crime through the adoption of forensic accounting; and companies must prevent any form of crime from being committed.

Azih \& Okoli (2015) carried out a study on forensic accounting as a veritable tool for efficient management of state owned public sectors in Ebonyi State: the Accountants' perspective. Their intention isto find out the uses of forensic accounting as well as the basic skills required for the use of forensic accounting in state owned public sectors in Ebonyi state, Nigeria. The population of the study comprised of One hundred and fifty six (156) Accountants working in the state ministries in Abakaliki. A sample size of sixty two (62) accountants was used. Out of sixty two (62) copies of the questionnaire distributed only sixty copies (60) were returned. In their study, they found out that forensic accounting is use to determining economic damages, the level of bankruptcy or insolvency for an organization, used to check on security fraud, used for valuation of a business, and they concludes that forensic accounting is very essential in all organization specifically in public sectors. They recommends that tertiary institutions offering accounting or accountancy should embraced forensic accounting as a course in their school both at undergraduate and post graduate level; and forensic accounting must be professionally practiced in Nigeria.

Similarly, Modugu \& Anyaduba (2013) in their study on Forensic Accounting and Financial Fraud in Nigeria: An Empirical Approach. The study specifically examined if there is significant agreement amongst stakeholders on the effectiveness of forensic accounting in financial fraud control, financial reporting and internal control quality. They used survey design in the study with a sample size of 143 consisting of accountants, management staffs, practicing auditors and shareholders. The simple random technique was utilized in selecting the sample size, while the binomial test was employed in the data analysis. The findings of the study indicate that there is significant agreement amongst stakeholders on the effectiveness of forensic accounting in fraud control, financial reporting and internal control quality. In line with the above findings, they therefore recommended that the Institute of Chartered Accountants of Nigeria, Association of National Accountants of Nigeria and the National Universities Commission should encourage formalization and specialization in the field forensic accounting. In addition, the government should stimulate interest in forensic accounting for monitoring and investigation of suspected corruption cases (Modugu \& Anyaduba, 2013).

Furthermore, Mukoro, Faboyede, \& Eziamaka (2014) explain in their paper title "the effectiveness of forensic accountants in strengthening internal control of business organizations in Nigeria: a study of selected business organizations in Nigeria". Their study aimed at investigating how fraud can be managed and handled in business organizations. Their research work was a survey research and sampling technique employed to achieve their objective was purposive sampling with a sample of five companies selected using Statistical Packages for Social Sciences (SPSS). They use Regression Analysis to test all their hypotheses. However, their findings show that internal control and its components play a significant role in controlling fraud in business organizations. They recommend that internal control should be undertaken with effective continuous monitoring of the controls; and 
companies should be stricter with compliance to control procedures (Mukoro et al, 2014).

On the other hand, Gbegi \&Adebisi (2013) carry out a study on the new fraud diamond model: how can it help forensic accountants in fraud investigation in Nigeria. Their study aims at broadening forensic accountant's knowledge about fraud and why it happens. They adopts secondary source of data to explain Wolf and Hermanson fraud theory and its relevance, presents fraud triangle models and relates them to Wolf and Hermanson's model, and they proposes a "New Fraud Diamond Model" (which include corporate governance) that Forensic Accountants could use while assessing the risk of fraud in Nigeria (Gbegi \&Adebisi, 2013).

Gbegi \& Adebisi (2015) carried out a study on analysis of fraud detection and prevention strategies in the Nigerian public sector. Their study aimed to analyze the incidence of fraud in the Nigeria public sector and the means of achieving a successful management of such fraud. They achieve their objective by raising some research questions, formulated hypothesis and reviewed some related literature. Their study population consisted of thirty (30) ministries in Nigeria from which sample size was drawn to twenty eight (28) ministries using Yaro Yamane's formula. Three hundred and ninety two (392) copies of the questionnaire distributed and three hundred and fifty (350) were filed and retrieved from respondents. Data collected were presented in Tables and analyzed using the means score, while analysis of variance (ANOVA) was used in testing the hypotheses with the aid of SPSS17.0. Findings in their study shows that, there is positive and significant relationship between management policies and Nigeria public sector fraud, fraud prevention and detection methods have influence on Nigeria public sector fraud, there is no strong internal control system in the Nigeria public sector and management integrity has influence on fraud prevention in the Nigeria public sector. They recommends in their study that, there is need for developing strong management policies; public sector should take advantage of modern accounting and auditing software to enhance efficient and smooth detection of fraud; there is need to build up strong internal control system in the public sector; and management integrity should be enforced.

Okoye \& Gbegi (2013) carried out a study that looks at an evaluation of forensic accountants to planning management fraud risk detection procedures. Their study was aimed at investigating the relative benefits of involving forensic accountants during the planning stage of developing an audit plan, which will effectively identify Management fraud. The methodology employed by them to back up their research work was Simple percentages mean and standard deviation were used to quantify the height of the variable. Multivariate Analysis of Variance (MANOVA) and Analysis of Variance (ANOVA) were also used for the comparison of their study with Asare \& Wright (2004) study. Their findings was that forensic accountants were effectively modify the extent and nature of audit test when the risk of Management fraud is high; Forensic accountants propose unique procedures that are not proposed by auditors when the risk of Management fraud is high; and involving Forensic Accountants in the risk of Management fraud assessment process leads to better results than simply consulting them. They recommend that Forensic Accountants should be involved in the planning stage of an audit, before and after the auditor has identified Management fraud risk factors; and there should be need for more training and accreditation of Forensic Accountants in Nigeria (Okoye \& Gbegi 2013).

However, Enofe, Ekpulu \& Ajala (2015) carried out a study on forensic accounting and corporate crime mitigation. Their objective is to examine forensic accounting and corporate crime mitigation in Nigeria. They used descriptive statistics and percentage analysis using Statistical package for social sciences (SPSS 17.0) to analyze the responses from the various respondents. Findings from their study indicate that forensic accounting could be a valuable tool in strengthening corporate governance which could help to curb the menace of corporate crime in Nigeria. They recommended that, corporate governance mechanisms should encompass forensic accounting in addition to its composition as contained in the Code of Best Practices on Corporate Governance as issued in 2003.

Olukowade \& Balogun (2015) conducted a research on relevance of forensic accounting in the detection and prevention of fraud in Nigeria. Their study was a theoretical research which considered the roles of forensic accountants in combating fraudulent activities, highlighted the differences between a forensic accountant and traditional accountant, features of a forensic accountant and the impact of forensic accountants to detect and prevent fraud. From their research work, it was found out that forensic accounting services will assist audit committee members in carrying out their oversight functions by providing assurance on internal audit report. They recommend that government should ameliorate the cost of hiring the services of forensic accountants and to treat culprits equally without any favoritism (Olukowade \& Balogun 2015).

Christopher (2004) carried out a study on an empirical investigation of the relevance and predictive ability of the SAS 99 fraud risk factors. He empirically examined the fraud risk factors adopted by the Accounting Standards Board in SAS No. 99 and developed a fraud prediction model that is useful in discriminating between fraud and no-fraud firms. His aim is to identifying and testing proxies for Cressey's fraud triangle (pressure, opportunity, and rationalization). The methodology adopted in his study is a step-wise logistic regression analysis of matched sample firms was used to evaluate the usefulness of the fraud risk factors in discriminating between fraud and nofraud firms; also in his study, he applied multiple discriminate analysis to the significant variables to develop a fraud prediction model in other to identifying the significant fraud risk factors. His findings indicate that users of 
publicly available data should take additional precautions when companies have audit committees with a low percentage of outside directors, high management ownership exceeding 5 percent, high cumulative percentage ownership in the firm held by insiders, and or a chief executive officer (CEO) who holds both the chief executive officer and Chairman of the Board position.

Tugas (2012) conducted a research on exploring a new element of fraud: a study on selected financial accounting fraud cases in the world. She was motivated to explore more on the elements of fraud by studying eight selected financial accounting fraud cases in the world vis-à-vis the review of the Report to the Nation on Occupational Fraud and Abuse for 2002, 2004, and 2008, and aims to explore a new element of fraud which can be evidenced by what happened to selected eight companies that were involved in financial accounting frauds so as to provide an answer to the question: "what can be common to the cases of the selected eight companies that were involved in financial accounting fraud?" In her study she employed exploratory and qualitative research design to position the occurrence of financial accounting fraud in the context of the fraud triangle and fraud diamond frameworks in the hope of exploring a new element of fraud evident in the eight cases that were established through the use of secondary data that were available from the reports taken from books and the Internet. Her findings reveal a new element of fraud which is called external regulatory influence which thereby extends fraud diamond theory to fraud pentagon theory. She recommends that (1) auditors should factor in external regulatory influence in the internal control checklist in the conduct of their audit; (2) top management should periodically review the code of corporate governance for changes regarding the mandate of external regulators; (3) the investors should include good governance as one of the criterion for choosing businesses to venture into, that is the business environments where there are strong culture of regulatory compliance and reportorial requirements; (4) the legal and regulatory bodies should enact a local law akin to Sarbanes-Oxley that will cater for the peculiar needs of the country.

\section{Gap in the Literature}

In view of the reviewed studies, we will agree with Wolf \& Hermanson (2004) said that many frauds would not have occurred without the right person with right mind carrying out fraudulent activities. This also was corroborated by Austin, (2014) quoted Hay, (2013) that capabilities have six supporting traits: positioning, intelligence, ego, coercion, deceit, and stress management.

This study clearly identify the absence of fraud risk management propositions from the empirical analysis because it is a known fact that fraud diamond theory shows various capability traits that fraudster must possess before fraud could be committed. Fraud risk management is to mitigate fraud occurrences; early detection, prevent and control. This explains the importance and relevance of this study. Fraud risk management provides necessary tools to manage risk in a manner consistent with regulatory requirements as well as the entity's business needs and user's expectations. The response to the fraud problem is not just in the regulatory environment and the supervision bodies, but in the companies' awareness that fraud usually happen and there is a stringent need to proactively manage fraud risk.

\subsection{Methodology}

This research is based on analytical and descriptive research in which simple random technique was used in collecting the data from respondents. It employs the use of survey in the collection of data because the respondents' opinions were sought through questionnaire.

Population of the Study: The total population of the study comprised of all public enterprises in Ondo State, Nigeria from which a sample population was drawn. The study focuses mainly on Account and Audit department of the public enterprises.

Sample Size of the Study: The sample size for the study equal 257 respondents purposively selected from the two groups of respondents.

Cochran formula cited by Kothari (2013) is used to determine the sample size. Using Cochran is that it is assumed that the entire work force (population) of the enterprise would be large. The formula is stated as follows:

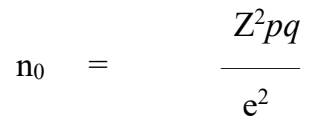

Where:

$\mathrm{n}_{0}=$ Sample size

$\mathrm{Z}^{2}=$ normal curve that cut off an area $\alpha$ at the tails

$P=$ estimated proportion in the population

$q=1-\mathrm{p}$

$\mathrm{e}=$ level of precision which is $5 \%(0.05)$

Confidence level of $95 \%$ 
Therefore: $(1.96)^{2}(.5)(.5)=385$

$(0.05)^{2}$

The sample size will determined thus:

$$
\mathrm{n}=\frac{\mathrm{n}_{0}}{1+\frac{\left(\mathrm{n}_{0}-1\right)}{\mathrm{N}}}
$$

Where: $\quad \mathrm{n}=$ sample size of the population

$\mathrm{N}=$ Population

Therefore: $\mathrm{n}_{0}=385 ; \mathrm{N}=770 ; \mathrm{n}=\underline{\underline{257}}$

Sampling Techniques: The study adopted purposive and random sampling technique to draw the sample from the entire specified work force or population (that is all the Account and Audit staff) of selected public enterprises in Ondo State. Primary information was collected by administering a questionnaire divided into two section: Section One contain personal data only; and section Two are divided into two parts: Part A is general questions consist of fifteen (15) questions; and while Part B is specific questions related to fraud risk indicators.

The techniques for distributing questionnaires to all the public enterprises stated as follows:

Individual Public Enterprises population

Total Population of Entire Public Enterprises

X Sample Size of the Population

Each of the respondents fills the questionnaire that was administered to them.

Sources of Data Collection: The researcher generates its data through primary source that was obtained by administering questionnaire to two (2) targeted groups: (i) Accountants; and (ii) Auditors working in the public enterprises in Ondo State and observation were used to measure the variables; while reviewing of various existing literatures from library; journals; articles and internet which are the secondary sources of data being used.

Method of Data Collection: Data were collected through the use of questionnaire administered to the respondents. The questionnaire consists of questions relevant to the study. It is structured, simple and clear for easy understanding. It is also divided into two sections namely: section (a) demographic data; and section (b) topical data respectively.

Research Instruments: In order to attain adequate, appropriate and reliable information, the study makes use of questionnaire to generate needed data. The independent variable is Forensic Accounting; and while dependent variable is Fraud risk Indicators which was break into four as follows: situational pressures of fraud risk indicators; personal characteristic of fraud risk indicators; opportunity of fraud risk indicators; and capability of fraud risk indicators.

Reliability of the Instruments: When the results of measuring instruments are consistent overtime, dependable and credible, then; the researchers' says that, if an instrument produce the same, consistent results overtime when applied to the same sample the measuring instrument is reliable. The study ensure that the instrument has high reliability, the questionnaire was constructed in a simple, concise and unambiguous, correction made with application of guides and explanations which enabled the respondents complete the questionnaire quickly and appropriately too. Furthermore, to ensure reliability of the instrument, draft copies of the questionnaire were administered to group of persons on the university campus at three different times to compare whether there will be consistency between their former response and the later. A reliability test of between $75-85 \%$ was recorded and attained.

Validity of the Instrument: The researcher ensures that the questionnaire is properly designed to measure what it was designed to measure; such that the content, concept of test items are relevant, appropriate and equally acceptable to respondents. And also, the researcher ensures that the content of the instrument is consistent with both objectives and hypotheses of the study.

\section{Technique of Data Analysis}

The data gathered from the questionnaire is presented and analyzed by employing Z-test using the 5 Likert scale responses by the respondents. Variables drawn from the topic make use of Likert scale. The Likert scales are: Strongly Agree-5, Agree-4, Undecided-3, Disagree-2, and Strongly Disagree-1, is logically employed to quantitatively reflect this order of ranking (Adefila, 2008).

All data generated were analyzed using Statistical Package for Social Sciences (SPSS 21) software.

Hence, the Z-test technique was used for testing the formulated hypotheses; the reason for using Z-test technique is because the sample size of the study is more than thirty.

\section{Procedure for Evaluation of Results:}

The arithmetic mean was used to compute the arithmetic mean of the data collected. Where expected mean is five 
(5.00) point scale; and the threshold is the midpoint of five (5.00) which is 2.50 thresholds. It is on these bases that any value that falls below 2.50 is insignificant

However, any value that is higher than 2.50 is considered to be significant.

Z-test

The table value of 2.38 at $5 \%$ level of significant was compared with the computed $\mathrm{Z}$-value.

\subsection{Presentation and Analysis of Data}

A total of 257 questionnaires were administered, two hundred and fifty-seven (257) questionnaires was duly completed and returned. However, only 238 were valid for analysis. That is, about ninety-two per cent $(92 \%)$ return rate. It is upon these 238 validly returned questionnaires that the analysis and inferences were made.

In consonance with the issues raised in the distributed questionnaires, the following responses were gotten from respondents, which are presented in tabular form alongside their frequencies and percentages which can be seen to be self-explanatory and easy to comprehend.

However, inferences from those tables that have direct bearing on the stated statements of hypotheses as contained in chapter one of this works were drawn with the use of Z-test research technique using the Statistical Package for Social Sciences (SPSS 21.0) software.

\section{Test Hypothesis}

In analysing the data, the study used the Z-test research technique for testing the formulated hypotheses. The obtained results are presented in table 4.2.1 below:

Table 4.2.1: Analysis of Data Using E-views 7 software

\begin{tabular}{|l|l|l|l|l|l|l|l|}
\hline Variable & Category & Mean & Df & SD & z-value & Prob. & Remark \\
\hline Situational Pressure & Accountant/Auditor & 56.7 & 2.38 & 7.33 & $8.05 *$ & 0.02 & Sig. \\
\hline Personal characteristic & Accountant/Auditor & 87.4 & 2.38 & 5.11 & $21.02^{*}$ & 0.00 & Sig. \\
\hline Opportunity & Accountant/Auditor & 33.9 & 2.38 & 2.89 & $11.32^{*}$ & 0.00 & Sig. \\
\hline Capability & Accountant/Auditor & 98.3 & 2.38 & 3.78 & $9.02 *$ & 0.02 & Sig. \\
\hline *Significant at 0.05 level
\end{tabular}

Source: Researcher's Computation August, 2018

The degree of freedom is given as: $(\mathrm{r}-1)(\mathrm{c}-1)$; where $\mathrm{r}=4, \mathrm{c}=2$.

$(4-1)(3-1)=3 \times 1=3$.

$\mathrm{Df}=3$ at $5 \%$ level of significance $=2.38$

\section{Interpretation of Results}

Table above shows from the result obtained that:

For situational pressure variable, the mean within the period of the study was 56.7 . The standard deviation value was 7.33. The z-value of 8.05 indicates that the obtained result is highly significant. Likewise, the probability value which was 0.02 lends credence to the statistical significance of the obtained result.

For personal characteristics variable, the mean within the period of this study was 87.4. The standard deviation value was 5.11 . The $\mathrm{z}$-value of 21.02 indicates that the obtained result is highly significant. Likewise, as indicated by the probability value which was 0.00 lend credence to the statistical significance of the obtained result.

For opportunity variable, the mean within the period of this study was 33.9. The standard deviation value was 2.89. The z-value of 11.32 indicates that the obtained result is highly significant. Likewise, as indicated by the probability value which was 0.00 lend credence to the statistical significance of the obtained result.

For capability variable, the mean within the period of this study was 98.3. The standard deviation value was 3.78. The z-value of 9.02 indicates that the obtained result is highly significant. Likewise, as indicated by the probability value which was 0.02 lend credence to the statistical significance of the obtained result.

\section{Summary of Findings}

The study attended to four specific research questions to find out, that; does forensic accounting help in detecting situational pressures related to fraud risk indicators in the public enterprises? does forensic accounting help in detecting personal characteristics related to fraud risk indicators in the public enterprises? does forensic accounting help in detecting opportunities related to fraud risk indicators in the public enterprises? and does forensic accounting help in detecting capabilities related to fraud risk indicators in the public enterprises.

These research questions were developed into research hypotheses to be tested.

In drawing decision based on the obtained results using the $\mathrm{z}$-values obtained; then, the research made to notes that, the statement of hypotheses one, two, three and four with references to the Table 4.2.1 (that is, data analysis table) presented above has direct bearing on stated objectives and hypotheses. 


\section{Recall statement of hypothesis one}

$\mathbf{H}_{\mathbf{0}}$ : Forensic accounting has no significant effect in detecting situational pressures related to fraud risk indicators in the public enterprises in Ondo State, Nigeria.

Decision making: from the computed mean results obtained, we observed that the calculated result is greater than the table result at the $5 \%$ level of significance i.e. $8.05>3.00$. Therefore, we reject the null hypothesis that Forensic accounting has no significant effect in detecting situational pressures related to fraud risk indicators in the public enterprises in Ondo State, Nigeria. That is, Forensic accounting has significant effect in detecting situational pressures related to fraud risk indicators in the public enterprises in Ondo State, Nigeria.

\section{Recall statement of hypothesis two}

$\mathbf{H}_{\mathbf{0}}$ : Forensic accounting has no significant effect in detecting personal characteristics related to fraud risk indicators in the public enterprises in Ondo State, Nigeria.

Decision making: from the computed results obtained, we observed that the calculated result is greater than the table result at the $5 \%$ level of significance i.e. $11.32>3.00$. Therefore, we reject the null hypothesis that Forensic accounting has no significant effect in detecting personal characteristics related to fraud risk indicators in the public enterprises in Ondo State, Nigeria.

\section{Recall statement of hypothesis three}

$\mathbf{H}_{\mathbf{0}}$ : Forensic accounting has no significant effect in detecting opportunities related to fraud risk indicators in the public enterprises in Ondo State, Nigeria.

Decision making: from the computation results obtained, it is observed that the calculated result is greater than the table result at the $10 \%$ level of significance i.e. $21.02>3.00$. Therefore, we reject the null hypothesis that Forensic accounting has no significant effect in detecting opportunities related to fraud risk indicators in the public enterprises in Ondo State, Nigeria.

\section{Recall statement of hypothesis four}

$\mathbf{H}_{\mathbf{0}}$ : Forensic accounting has no significant effect in detecting capabilities related to fraud risk indicators in the public enterprises in Ondo State, Nigeria.

Decision making: from the computed results obtained, it is observed that the calculated result is greater than the table result at the $5 \%$ level of significance i.e. $9.02>3.00$. Therefore, we reject the null hypothesis that Forensic accounting has no significant effect in detecting capabilities related to fraud risk indicators in the public enterprises in Ondo State, Nigeria.

However, the study findings aligns with Azih \& Okoli (2015) who carried out a study on forensic accounting as a veritable tool for efficient management of state owned public sectors in Ebonyi State, Nigeria; they found out that forensic accounting is use to determining economic damages, the level of bankruptcy or insolvency for an organization, used to check on security fraud, used for valuation of a business, and they concludes that forensic accounting is very essential in all organization specifically in public sectors.

And also, the studies of Enofe, Olorunnuho \& Eboigbe (2015) and Enofe, Okpako \& Atube (2013) when they examined the effect of forensic accounting on fraud detection in Nigerian firms, the findings of their study reveal that the application of forensic accounting has strong relationship with fraud detection for public confidence, eradication of crime and corruption.

\subsection{SUMMARY, CONCLUSION AND RECOMMENDATIONS}

SUMMARY: This work is on effect of Forensic Accounting on the Detection of Fraud Risk indicators in Public Enterprises in Ondo State, Nigeria; the main objective of this research work is to examine the effects of forensic accounting on detecting fraud risk indicators in the public enterprises in Ondo State. The study also seeks to examine how forensic accounting can be used in detecting situational pressures, personal characteristics, opportunities, and capabilities of fraud risk indicators in the public enterprises in Ondo State, Nigeria. Though fraudulent practice has become a global phenomenon of the 21 st century, in Nigeria the problem is a disturbing menace that is also known as corruption. Frauds case in public enterprises in Nigeria is a going concern, given its widespread and devastating effect on the Nigerian State.

With regard to the study area Ondo State, findings showed that Forensic Accounting does have significant effect with regards to detection of fraud risk indicators in Public Enterprises. That is, effective use of the forensic accounting could help in the detection of fraud risk indicators that often leads to continuous perpetration of fraud in the Public Enterprises in Ondo State. In addition, the study findings also revealed that forensic accounting has greatly assisted in detecting situational pressures, personal characteristics, opportunities, and capabilities related fraud risk indicators in the public enterprises in Ondo State, Nigeria. Although, considering the waves and massiveness of the fraudulent acts that were been perpetuated in the public enterprises, it was observed that forensic accounting can only make less the effect of corrupt practices in the system. 
CONCLUSION: This study looked at the effect of Forensic Accounting on the Detection of Fraud Risk indicators in Public Enterprises in Ondo State, Nigeria. The outcome of this study shows that there are evidences that forensic accounting is significant in the detection of fraud risk indicators in Public Enterprises in Ondo State, Nigeria. This is not to say that forensic accounting system has completely eradicated fraudulent practices given the massiveness of corrupt related acts in the public enterprises. Forensic accounting to an extent has helped to reduce cases of fraud particularly those related to fraud risk indicators in the public enterprises. Fraud perpetrators feel justified; and that they must counter the following such as moral, legal and consequences.

It is evident in this study that the effectiveness of any forensic accounting techniques for combating fraudulent activities depend more on risk management framework put in place by the business's management. This is because, the risk management framework will provide an organization with necessary tools to manage risk in a manner consistent with regulatory requirements as well as the entity's business needs and users' expectations. This is a way of mitigating fraud occurrences; early detection, prevention and control.

Control is expected to pose a visible and highly threat of apprehension of fraud perpetrators; while perception of detection will be of a greatest deterrent but hidden control would not deter the fraudsters.

\section{RECOMMENDATIONS:}

The study proposes the following recommendations below which need prompt actions.

i. It is recommended among other things that since, forensic accounting has significant effect in the detection of fraud risk indicators related fraud in the Public Enterprises, in Ondo State; the Government should endeavour to increase the use of forensic accounting system in all parastatals and agencies of government.

ii. In order to further curb related fraud risk indicators that are made possible by situational pressures, personal characteristics, opportunities, and capabilities in the public enterprises in Ondo State, Nigeria; there is need for value re-orientation training and seminar so as to be able renew the mindset of the workers towards integrity and uprightness.

iii. Although, the study findings revealed that forensic accounting has been impacting on the Public Enterprises in Ondo State but when compared to the massiveness of fraud still being perpetrated in some quarters, the situation calls for urgent attention. In this regard, the study recommends that adequate and commensurate punishment be meted out to anyone caught in fraudulent act to serve as deterrent to as many that have such dastard thought and plan.

iv. The effectiveness of any forensic accounting technique for combating fraudulent activities depends on risk management framework put in place by the organisation. This is in line with the guidelines on responsibilities for the oversight and management corporate risk (International Corporate Governance Network (ICGN), 2010). Therefore, the study recommends that, the establishment of risk control department or unit; and possible workable risk management framework will reduce any related fraud risk in the public enterprises in Nigeria as a whole.

LIMITATIONS OF THE STUDY: The first limitation of this research is about detection of related fraud risk indicators in the public enterprises business in a developing country, Nigeria. Finding out the effect of forensic accounting on detection of fraud risk indicators and influence of fraud theory in the public enterprises is considered sensitive and may be bias.

The second limitation is the restriction of this study to Ondo State only, out of the 36 states in Nigeria, may question the generalization of the research findings; also the study was associated with inadequate time frame and availability of information or data.

Lastly, the study focuses mainly on fraud diamond theory and failed to harness the proposition of Gbegi \& Adebisi (2013) "the New Fraud Diamond Theory" which they posited that the "corporate governance" that they added to the existing fraud diamond theory will make forensic accounting practitioners to have in-depth knowledge of fraud and why it occurs; and also, Tugas F. O. (2012) says "External Regulatory Influence" should be equally added to the existing fraud diamond theory to be called "Fraud Pentagon Theory".

Hence, the results might have been different if the two new researchers' points (Gbegi \& Adebisi, and Tugas F. O.) must be considered in the work; and as well the timely availability of data would have make the study more suitable.

CONTRIBUTION TO KNOWLEDGE: This study is on the effect of Forensic Accounting on the Detection of Fraud Risk indicators in Public Enterprises in Ondo State, Nigeria. In this work, the followings were the areas it has contributed to knowledge:

i. Attempt has been made in this study to unravel how fraud risk indicators related to fraud can be curbed in the public enterprise which has added to literatures in this area of study.

ii. For measuring effect of forensic accounting on the detection of fraud risk indicators in Public Enterprises in Ondo State, Nigeria, its contribution to knowledge in this regard is commendable. Besides, the study double as a feedback tool for the government from which future policy design and framework can be drawn.

Suggested Area for Future Study: Further studies in this area can take a look at the following: 
i. The effect of forensic accounting on corrupt practice in the civil service in Nigeria.

ii. The use of fraud risk indicators in curbing fraud related practice in the Nigerian civil service.

\section{REFERENCES:}

Abdullah, T. T. Y. Alfadhl, M. M. A. Yahya, S. \& Rabi, A. M. A. (2013), The role of forensic accounting in reducing financial corruption: A study in Iraq. International Journal of Business and Management; 9 (1) Published by Canadian Center of Science and Education URL: http://dx.doi.org/10.5539/ijbm.v9n1p26 Retrieved from goggle on December 14, 2016

Adeniyi, A. (2004), Auditing and Investigation. Second edition. Lagos, El-Toda Ventures Limited.

Albrecht, W. S. (2005), Identifying Fraudulent Financial Transactions: A Framework for Detecting Financial Statement Fraud. Brigham Young University. Retrieved on January10, 2017 from www.maaw.info/JournalofForensicAccounting.htm

Association of Certified Fraud Examiners (ACFE) (2010), Fraud Examiners Manual (Intentional) Association of Certified Fraud Examiners (ACFE). London: McGraw Publishers.

Augustine, E. A. \&. Uagbale-Ekatah, R. E. (2014), The Growing Relevance of Forensic Accounting as a Tool For Combating Fraud and Corruption: Nigeria Experience. Research Journal of Finance and Accounting 5, (2), (Pp. 71 - 74). Retrieved from goggle on April 13, 2017

Austin, T. (2006), 2006ACFE Report to the Nation on occupational fraud. usa: www.sequence inc.com/fraud files/20. Retrieved on Februar 15, 2018

Azih, N. \& Okoli, B. E. (2015), Forensic accounting as a veritable tool for efficient management of state owned public sectors in Ebonyi State: the Accountants' perspective. British Journal of Education 3 (8), (Pp. 55 - 62) Published by European Centre for Research Training and Development UK (www.eajournals.org) Retrieved on February 9, 2018

Beredugo, S. B., Inah, E. U. \& Edom, G. O. (2014), Appraisal of Forensic Investigation and Auditors' Liability: Empirical Evidence from Nigeria. The International Journal Of Business \& Management (ISSN 2321 - 8916) 2 (10), www.ijbm.com Retrieved from goggle on March 20, 2016

Chartered Institute of Management Accountants (2009), Fraud risk management: A guide to good practice London SW1P 4NP; United Kingdom: Retrieved from www.cimaglobal.com on June 14, 2017

Christopher, J. S. (2004), An empirical investigation of the relevance and predictive ability of the SAS 99 fraud risk factors. ' https://www.researchgate.net/publication/265245085 Retrieved on July 22, 2016

Dinapoli, T. P. (2010), Red Flags for Fraud, New York: State of New York Office the State Comptroller. Http://Www.Osc.State.Ny.Us/Localgov/Pubs/Red_Flags Fraud. Retrieved on November 16, 2016

Dzamba, A. (2004), 36 Red Flags To Look For When Reviewing Financial Reporting Controls. Financial Analysis, Planning \& Reporting. 4 (8), (Pp 1 - 12)

EFCC (2004), Obstacles to Effective Prosecution of Corrupt Practices and Financial Crime Cases in Nigeria. Paper Presented at the 1st Stakeholders Summit on Corrupt Practices and Financial Crimes in Nigeria Organized by House of Representatives Committee on Anti-Corruption, National Ethics and Values at the International Conference Center, Trade Fare Complex, Kaduna, EFCC Publication.

Enofe, A.O. Okpako, P.O. \& Atube, E.N. (2013), The Impact of Forensic Accounting On Fraud Detection. European Journal of Business and Management 5 (26), (Pp. 61 - 74) Retrieved www.academia.edu on October 11, 2016

Enofe, A. O. Ekpulu, G. A. \& Ajala, T. O. (2015), Forensic accounting and corporate crime mitigation. European Scientific Journal March 2015 edition 11 (7) ISSN: 1857 - 7881 Retrieved on March 20, 2017

Enofe, A.O. Onyeokweni, O.V. \& Onobun, S. I. (2015), Forensic Accounting and Financial Crime. International Journal of Multidisciplinary Research and Development 2 (9), (Pp. 213 - 219) www.allsubjectjournal.com Retrieved on September 19, 2017

Ernst \& Young (2003), Fraud, the Unmanaged Risk: Retrieved from www.ey.com on August 10, 2017

Faboyede, O. S. (2009), Forensic Accounting and the Law: Two Sides of a Coin. Retreived from www.businessdayonline.com/forensic-accounting-and-the-law-two-sides-of-acoin on March 18, 2017

Freddie, Chaoo and Kim, Tan (2007), An American Dream: Theory of Corporate Executive Fraud. Elsevier Limited, CA 94132, United State.

Gbegi, D. O. \& Adebisi, J. F. (2013), The New Fraud Diamond Model- How Can it Help Forensic Accountants in Fraud Investigation in Nigeria? European Journal of Accounting Auditing and Fiancé Research 1 (4), (Pp.129 - 138), December 2013 Retrieved on March 9, 2018 from www.eajournals.org

Gbegi, D. O. \& Adebisi, J. F. (2015), Analysis of fraud detection and prevention strategies in the Nigerian public sector. Journal of Good Governance and Sustainable Development in Africa(JGGSDA), 2 (4), May, 2015. http://www.rcmss.com. ISSN: 2354-158X (Online) ISSN: 2346-724X (Print). Retrieved on March 9, 2017

Gbegi, D. O. \& Adebisi, J. F. (2014), Forensic Accounting Skills and Techniques in Fraud Investigation in the Nigerian Public Sector. Mediterranean Journal of Social Sciences MCSER Publishing, Rome-Italy, 5 (3), (Pp 
243 - 252) Retrieved from Google March 9, 2016

Golden T, Skalak S, Clayton M (2006), A Guide to Forensic Accounting Investigation, John Wiley \& Sons.

Hooper, M. J. \& Pornelli, C. M. (2010), Deterring and Detecting Financial Fraud: A Platform For Action. Retrieved on March 17, 2018 from Http:/Www.Thecaq.Org/Docs/Reports-and-Publications/Deterring-andDetecting.Financial-Reporting-Fraud-A-Platform-For-Action

Institute of Chartered Accountants of Nigeria (2014), Management, Governance and Ethics. First edition. Emile Woolf International, United Kingdom.

International Corporate Governance Network (2010), Guidelines on Responsibilities for the Oversight and Management Corporate Risk.

Jaffar, N. Salleh, A. Mohd Iskandar, T. and Haron, H. (2007), The Effect of Fraud Risk Assessment on the External Auditor's Ability to Detect The Likelihood of Fraud: A Conceptual Discussion, European Journal of Scientific Research, 2007, 17 (3), (Pp. 425-432). Retrieved from Goggle on March 15, 2018

Kasum, A. S. (2009). The Relevance of Forensic Accounting to Financial Crimes in Private and Public Sectors of Third World Economies: A Study from Nigeria. Proceedings of the 1st International Conference on Governance Fraud Ethics and Social Responsibility, (pp. 11-13). Retrieved from Google March 16, 2018

KPMG (2007), Profile of a Fraudster Survey.www.kpmg.co.uk/pubs/ProfileofaFraudsterSurvey Retrieved on Aug. 15,2018

Laleye, O. M. (1985). The Role of Public Enterprises in the Development of Nigeria. unpublished PhD. Thesis, University of Ife, Ile-Ife.

Lister, L. M. (2007), A Practical Approach to Fraud Risk: Internal Auditor.

Manurung, D.H. \& Hadian N. (2013), Detection Fraud of Financial Statement with Fraud Triangle, Proceedings of 23rd International Business Research Conference. Marriott Hotel, Melbourne, Australia Retrieved from goggle on March 17, 2017

Moyes, G. Mohd, H. \& Omar, N. (2009), The Effectiveness of the Auditing Standards to Detect Fraudulent Financial Reporting Activities in Financial Statement Audits in Malaysia, International Business \& Economics Research Journals, 2009, 8 (9), (Pp. 1-17), Retrieved from www.google.com on March 17, 2017

Murdock, H. (2008), The Three Dimensions of Fraud: Internal Auditors. Retrieved on March 16, 2017 from www.emerald.com

Nellis J. (1986). Public Enterprises in Sub-Saharan Africa. World Bank Discussion Paper No. 1, Washington, D.C. World Bank.

Obadan, M. \& S. Ayodele (1998). Commercialization and Privatization Policy in Nigeria. Ibadan: National Centre for Economic Management and Administration.

Obadan, M. I. (2000). Privatization of Public Enterprises in Nigeria. Issues and Conditions for success in the Second Round Ibadan: National Centre for Economic Management and Administration.

Okafor, B. (2004), Strategic approach to reduction of employee, theft fraud and embezzlement. ijbssnet.com/journals/ 4 (9), Retrieve from www. ijbssnet.com on March 21, 2017

Okoye, E. I. \& Gbegi, D. O. (2013). Forensic accounting: A tool for fraud detection and prevention in the public sector. (A study of selected ministries in Kogi state). International Journal of Academic Research in Business and Social Sciences, 3 (3), (Pp. 1-19). Retreived from goggle on March 17, 2017

Okunbor, J. A. \& Obaretin, O. (2010). Effectiveness of the Application of Forensic Accounting Services in Nigerian Corporate Organizations. AAU JMS, 1 (1), Retrieved from goggle on March 17, 2017

Olukowade, E. \& Balogun, E. (2015), Relevance of forensic accounting in the detection and prevention of fraud in Nigeria. Historical Research Letter volume 23, 2015 www.iiste.org Retrieved on March 17, 2017

PricewaterhouseCoopers, (2007), Economic Crime: people, culture and controls the $4^{\text {th }}$ biennial Global Economic Crime Survey, www.pwc.com/crimesurvey. Retrieved from goggle on March 17, 2017

Sosna, S. A. (1983). Public Enterprises in Developing Countries, Legal Status. Moscow, Progress Publishers.

The Association of certified fraud examiners (ACFE), (2008), Report to the Nation on Occupational Fraud and Abuse, www.acfe.org Retrieved from goggle on March 18, 2017

The Association of certified fraud examiners (ACFE). (2008), Fraud Examiners Manual. Retrieved from goggle on March 18, 2017

Tugas, F. C. (2012), Exploring a new element of fraud: a study on selected financial accounting fraud cases in the world. American International Journal of Contemporary Research 2 (6), www.aijcrnet.com Retrieved on March 20, 2017

Wells, J., (2007), corporate fraud handbook: prevention and detection. $2^{\text {nd }}$ edition Hoboken, NJ: John Wiley and Sons.

Wells, J. (2004), New Approaches to Fraud Deterrence. Journal of Accountancy, (Pp. 203 - 212) Retrieved from goggle on March 19, 2017

Wolfe, D. T. \& Hermanson, D. R. (2004), The Fraud Diamond: Considering the Four Element of Fraud, The New York State Society of Certified Public Accountants. Retrieved from www.google.com on March 14, 2017 
Wells, J.T. (2011), Corporate Fraud Handbook: Prevention and Detection. Third Edition: Hoboken, New Jersey: John Wiley \& Sons Inc.

Vona, I.W. (2008). Fraud Risk Assessment: Building a Fraud Audit Programm. Hoboken, New Jersey: John Wiley and Sons.

www. forensicaccounting.com/there.htm. 